Available online at GSC Online Press Directory

GSC Biological and Pharmaceutical Sciences

e-ISSN: 2581-3250, CODEN (USA): GBPSC2

Journal homepage: https://www.gsconlinepress.com/journals/gscbps

(REVIEW ARTICLE)

\title{
New perspectives in male infertility
}

\author{
Akilah Amira A. ${ }^{1}$, Kabel Ahmed M. ${ }^{1,2 *}$, Alharthi Huda A. ${ }^{3}$ \\ ${ }^{1}$ Department of Pharmacology, Faculty of Medicine, Tanta University, Tanta, Egypt \\ 2 Department of Clinical Pharmacy, College of Pharmacy, Taif University, Taif, Kingdom of Saudi Arabia \\ ${ }^{3}$ Pharm D, King Faisal Hospital, Taif, Kingdom of Saudi Arabia
}

Publication history: Received on 27 September 2017; revised on 03 November 2017; accepted on 09 November 2017

https://doi.org/10.30574/gscbps.2017.1.3.0027

\begin{abstract}
Male infertility refers to inability of the male partner to make a fertile female to get pregnant. In humans, it represents about $40-50 \%$ of cases of infertility. It occurs most frequently due to either decrease in the quantity of living spermatozoa or defects in semen quality. Causes of male infertility are variable, including pre-testicular, testicular and post-testicular factors. Diagnosis usually needs taking full medical history together with performing thorough physical examination and laboratory and radiological investigations. Management of male infertility is individualized according to the incriminated cause of infertility and the available methods of intervention. Recently, prognosis of cases of male infertility had significantly improved with the advancement in the methods of laboratory and radiological diagnosis together with the improvement in the assisted reproductive techniques. Further studies are needed to develop new techniques for management of resistant cases of male infertility.
\end{abstract}

Keywords: Infertility; Male; Diagnosis; Management; Perspectives

\section{Introduction}

Infertility is a distracting major health problem that affects the human beings especially when the cause of infertility is the male partner [1]. It is defined as inability of a sexually active couple not using contraception, to achieve pregnancy within one year of regular intercourse. Male infertility is usually attributed to deficiencies in the semen quality [2]. It accounts for about 30-40 \% of overall cases of infertility and it affects approximately 7\% of all males worldwide [3].

Normally, the hypothalamus secretes gonadotropin releasing hormone (GnRH) in a pulsatile manner to reach the pituitary gland which in turn secrets gonadotropins including follicle stimulating hormone (FSH) and luteinizing hormone (LH), which are targeting the testes [4]. FSH goes to the sertoli cells where it stimulates primary spermatocytes to undergo Meiosis I to secondary spermatocytes and then mature sperms [5]. Also, FSH stimulates the Sertoli cells to release andogen binding protein (ABP) which binds to testosterone that is released from Lydig cells preventing its metabolism to estradiol and also facilitates testosterone transport inside the seminiferous tubules. Moreover, FSH promotes the release of inhibin hormone which exerts a negative feedback regulatory effect at the pituitary level to decrease FSH release [6]. LH reaches the Leydig cells in the interstitial tissues between the seminiferous tubules where it stimulates the release of androgens (mainly testosterone). Any disturbance of the above regulatory mechanisms could lead to subfertility or even infertility in males [7]. This review sheds light on the novel perspective in male infertility regarding its etiology, methods of diagnosis, prognosis and possible lines of management.

\footnotetext{
${ }^{*}$ Corresponding author

E-mail address: drakabel@ gmail.com
}

Copyright (C) 2017 Author(s) retain the copyright of this article. This article is published under the terms of the Creative Commons Attribution Liscense 4.0. 


\section{Etiology}

\subsection{Testicular factors}

Testicular factors include conditions in which the testes produce sperms of low quantity and/or quality despite adequate hormonal support. They include varicocele which represents up to $35 \%$ of cases of primary infertility and 69 $81 \%$ of cases of secondary infertility [8]. Other factors include age, genetic defects on the Y chromosome, Klinefelter syndrome, tumors such as seminoma, cryptorchidism, testicular trauma, mumps, hydrocele, infection with malaria, acrosomal defects affecting egg penetration and exposure of the testes to radiation therapy [9].

\subsection{Pre-testicular factors}

Pre-testicular factors include those which interfere with adequate support of the testes and include hypogonadotropic hypogonadism due to various causes such as obesity. Experimental models in animals indicated that the most common cause of leptin insensitivity in the hypothalamus is obesity, which responsible for decreased Kiss1 expression, which consecutively changes the release of gonadotropin-releasing hormone (GnRH) [10]. Also, undiagnosed and untreated coeliac disease can decrease semen quality and cause immature secondary sex characters, hypogonadism and hyperprolactinaemia which may lead to impotence and loss of libido. It is recommended that an effective evaluation for infertility must include assessment for underlying celiac disease, both in males and females [11].

Medications such as anabolic steroids, chemotherapeutic agents, cimetidine, phenytoin, spironolactone and sulfasalazine may affect the spermatogenesis process, reduce FSH levels or markedly decrease sperm motility [12]. In addition to this, genetic abnormalities such as a Robertsonian translocation may be an important cause of male infertility [13]. Moreover, the harmful products of tobacco smoking may damage the testicles and kill sperms. Tobacco smoking was proven to increase the daily intake of cadmium, which may replace zinc in the DNA polymerase enzyme, which affects the process of spermatogenesis leading to serious damage to the testes [14].

Another pre-testicular factors that may be involved in the pathogenesis of male infertility are the common inherited variants in genes that encode enzymes involved in DNA mismatch repair leading to increased risk of sperm DNA damage and male infertility [15]. Recent studies revealed increasing amount of documented abnormal sperm DNA methylation in association with abnormal semen parameters and male infertility [16].

\subsection{Post-testicular factors}

Post-testicular factors may cause male infertility by affecting the male genital system after sperm production. They include defects of the genital tract as well as ejaculation dysfunction such as vas deferens obstruction, congenital absence of vas deferens, prostatitis, ejaculatory duct obstruction, retrograde ejaculation, hypospadias and impotence [10].

\section{Diagnosis}

Diagnosis of male infertility necessitates taking full medical history and performing thorough physical examination by the physician in addition to laboratory and radiological investigations. Typically, two separate semen analyses will be needed in addition to blood tests to exclude hormonal imbalance, medical conditions or genetic defects [17].

\subsection{Medical history}

The history taken by the physician should include history of previous testicular or penile insults such as testicular trauma, torsion or cryptorchidism, infections such as mumps, orchitis or epididymitis, environmental factors, exposure to excessive heat or radiation, and intake of drugs that may affect spermatogenesis such as anabolic steroids, cimetidine, spironolactone or alcohol [18]. Similarly, asking the patient about his sexual habits, frequency and duration of the intercourse, use of lubricants during the sexual act and each partner's previous fertility experiences are extremely important for diagnosis of the precipitating factors for male infertility [9]. History of visual disturbances, headache or decreased libido may be strong indicative factors for diagnosis of a pituitary tumor. Previous history of thyroid or liver disease, diabetic neuropathy, hernia repair, radical pelvic or retroperitoneal surgery may be important to reveal any medical or surgical predisposing factors to male infertility. Also, family history may reveal possible genetic problems that may affect spermatogenesis [17]. 


\subsection{Physical examination}

The physician should perform a thorough examination of the external genitalia, urethra, urinary bladder, rectum and anus. Physical examination of the scrotum may reveal the presence of varicocele, tumors or abnormal cysts [19].

\subsection{Laboratory and radiological investigations}

Semen analysis is the golden laboratory investigation for diagnosis of male infertility. Volume of semen, total number of spermatozoa, sperm motility and the percent of abnormal forms of sperms are measured. This test may detect oligospermia, azoospermia, hypospermia, aspermia, teratospermia or asthenozoospermia. Low sperm counts are often associated with decreased sperm motility and increased abnormal morphology of the sperms [20]. Also, blood tests for determination of FSH, LH and testosterone levels may detect hormonal causes of male infertility. Genetic defects such as Klinefelter syndrome, Y chromosome microdeletion or cystic fibrosis may be revealed by examination of blood samples [21].

Scrotal ultrasonography may detect signs of testicular dysgenesis or testicular tumors. Also, decreased testicular vascularization detected by ultrasonography is characteristic of testicular torsion, while hyperemia is observed in epididymo-orchitis or in some malignant conditions such as lymphoma and leukemia [22]. Doppler ultrasonography useful in assessment of venous reflux in cases of varicocele. Ultrasonography can also detect dilation of the head or tail of the epididymis which is suggestive of obstruction or inflammation of the male reproductive tract. Scrotal and transrectal ultrasonography may detect congenital absence of the vas deferens which may be associated with abnormalities of the epididymis, seminal vesicles or the kidney [23].

\section{Prevention}

Preventive measures are indicated for patients at risk of developing infertility such as heavy smokers and some industrial workers [24]. Some strategies were proposed to avoid male infertility including avoidance of smoking, avoidance of heavy marijuana and alcohol use, avoidance of exposure of the testes to excessive heat and maintaining optimal frequency of coital activity. Also, wearing a protective cup and jockstrap to protect the testicles is recommended in any sport in which the testes may be exposed to external trauma [25].

\section{Treatment}

Lines of treatments vary widely according to the underlying disease and the degree of the impairment of the male fertility. Also, in any male infertility situation, the fertility of the female partner should be considered. Pre-testicular conditions can often be managed by medical treatment (Table 1) or surgical interventions [19]. Cases of male infertility in which testicular factors are the incriminated causes tend to be resistant to medical treatment. Management of these cases usually includes using the sperms for intrauterine insemination, in vitro fertilization (IVF) or IVF with intracytoplasmatic sperm injection [26]. Obstructive causes of post-testicular male infertility can be managed with either surgery or IVF with intracytoplasmatic sperm injection. Ejaculatory dysfunctions may be treated by either medical therapy, intrauterine insemination or IVF [27].

Antioxidants such as vitamin C, vitamin E, selenium, coenzyme Q10, L-carnitine and omega 3 fatty acids may help to relieve oxidative stress, which is considered as the main causative factor for DNA damage and decreased motility of the spermatozoa [28]. A combination of antioxidants with hormonal therapy may improve sperm count and motility and decrease abnormal sperm morphology [29]. Administration of LH or human chorionic gonadotropin and FSH is very effective in treatment of male infertility due to hypogonadotropic hypogonadism [30]. Although controversial, antiestrogens such as clomiphene citrate may be effective in management of male infertility by elevating gonadotropin levels [31]. Also, aromatase inhibitors such as anastrozole or testolactone may be effective for improvement of spermatogenesis [32]. Low-dose estrogen and testosterone combination therapy may improve sperm count and motility in some men, including those with severe oligospermia [33].

Recent studies had developed in vitro culture conditions using a three-dimensional agar culture system which induces mouse testicular germ cells to reach the final stages of spermatogenesis, including generation of spermatozoa [34]. If reproduced in humans, this might enable infertile men to father children with their own sperm [35]. Also, precursors of sperms from skin cells of infertile men were developed and might be a promising hope for management of male infertility [36]. 
Table 1 Medical treatment of male infertility

\begin{tabular}{|c|c|c|c|}
\hline Treatment option & Mechanism & Advantages & Disadvantages \\
\hline $\begin{array}{l}\text { Pulsatile gonadotropin- } \\
\text { releasing hormone (GnRH) }\end{array}$ & $\begin{array}{l}\text { Stimulate gonadotropin } \\
\text { release from the pituitary gland }\end{array}$ & $\begin{array}{l}\text { specific treatment } \\
\text { option for male } \\
\text { infertility due to } \\
\text { hypogonadotropic } \\
\text { hypogonadism (e.g., } \\
\text { Kallmann's syndrome) }\end{array}$ & $\begin{array}{l}\text { Failed as empirical } \\
\text { therapy for idiopathic } \\
\text { male } \\
\text { expensive, infertility, } \\
\text { require frequent change } \\
\text { of needles, formation of } \\
\text { anti-GnRH antibodies }\end{array}$ \\
\hline $\begin{array}{l}\text { Human chorionic } \\
\text { gonadotropin (hCG) }\end{array}$ & $\begin{array}{l}\text { Closely related to } \mathrm{LH} \\
\text { properties }\end{array}$ & & $\begin{array}{l}\text { Aromatase inhibitors } \\
\text { may be added }\end{array}$ \\
\hline $\begin{array}{l}\text { Human menopausal } \\
\text { gonadotropins (hMG) }\end{array}$ & $\begin{array}{l}\text { Closely related to } \mathrm{FSH} \\
\text { properties }\end{array}$ & & \\
\hline Recombinant FSH and LH & Stimulate spermatogenesis & & \\
\hline $\begin{array}{l}\text { Anti-Estrogens: } \\
\text { Clomophine citrate, } \\
\text { Tamoxifene }\end{array}$ & $\begin{array}{l}\text { Normal/high FSH and low or } \\
\text { normal testosterone level }\end{array}$ & $\begin{array}{l}\text { Inhibit negative } \\
\text { feedback of estrogen on } \\
\text { pituitary and } \\
\text { hypothalamus, } \\
\text { increases release of } \\
\text { GnRh, FSH and LH } \\
\text { which in turn stimulate } \\
\text { spermatogenesis and } \\
\text { steroidogenesis. }\end{array}$ & $\begin{array}{l}\text { Elevate the } \mathrm{T} \text { level as } \\
\text { well as } \mathrm{E} 2 \text { which may } \\
\text { decrease the extent of } \\
\text { elevated } \mathrm{T} \text { level so } \\
\text { aromatase inhibitors } \\
\text { may be added to } \\
\text { clomiphene therapy }\end{array}$ \\
\hline $\begin{array}{lr}\text { Aromatase } & \text { inhibitors }(2 \\
\text { types): } & \text { Steroidal } \\
\text { (testolactone) } & \text { or Non- } \\
\text { steroidal } & \text { (Anastrozol, } \\
\text { Letrozole) } & \end{array}$ & $\begin{array}{l}\text { Low testosterone and high } \\
\text { aromatase enzyme activity } \\
\text { converting T to E2 }\end{array}$ & $\begin{array}{l}\text { Used in infertility } \\
\text { associated with obesity, } \\
\text { hyperestrogeneamia } \\
\text { and empirical in } \\
\text { idiopathic infertility }\end{array}$ & Osteoporosis, Joint pain \\
\hline $\begin{array}{l}\text { Dopamine } \\
\text { (cabergolide, } \\
\text { bromocryptine) }\end{array}$ & $\begin{array}{l}\text { If high prolactin and low } \\
\text { testosterone } \\
\text { gonadotropins }\end{array}$ & $\begin{array}{l}\text { Used to treat cases of } \\
\text { male infertility due to } \\
\text { hyperprolactineamia }\end{array}$ & $\begin{array}{l}\text { Failed to be used as an } \\
\text { empirical treatment for } \\
\text { idiopathic } \\
\text { headache, cases, } \\
\text { hypotension, nostural } \\
\text { and sleepiness }\end{array}$ \\
\hline L-carnitines & $\begin{array}{l}\text { Generating cellular energy via } \\
\text { beta-oxidation by transporting } \\
\text { fatty acyl groups across the } \\
\text { inner mitochondrial } \\
\text { membrane and inhibit lipid } \\
\text { peroxidation. }\end{array}$ & $\begin{array}{l}\text { In human, the } \\
\text { concentration of free L- } \\
\text { carnitine is highest in } \\
\text { epididymal plasma and } \\
\text { spermatozoa where it } \\
\text { concentrated in both } \\
\text { the free and acetylated } \\
\text { forms and responsible } \\
\text { mainly for sperm } \\
\text { motility }\end{array}$ & \\
\hline $\begin{array}{l}\text { Coenzyme Q10 } \\
\text { (ubiquinone) }\end{array}$ & $\begin{array}{l}\text { A component of the electron } \\
\text { transport chain, participating } \\
\text { in aerobic respiration and the } \\
\text { generation of energy. }\end{array}$ & $\begin{array}{l}\text { It has direct anti- } \\
\text { oxidant activity, }\end{array}$ & \\
\hline
\end{tabular}




\begin{tabular}{|c|c|c|c|}
\hline Selenium & $\begin{array}{l}\text { Selenium is a non-metal } \\
\text { element that is an essential } \\
\text { part of important anti-oxidant } \\
\text { enzymes such as glutathione } \\
\text { peroxidase. }\end{array}$ & $\begin{array}{l}\text { Increases the levels of } \\
\text { glutathione peroxidase } \\
\text { and reductase in } \\
\text { sperms. }\end{array}$ & \\
\hline Bisolvon & $\begin{array}{l}\text { Used in cased of high viscosity } \\
\text { impairing sperm movement for } \\
\text { only } 3 \text { days no more }\end{array}$ & & \\
\hline Vitamin C (ascorbic acid) & $\begin{array}{l}\text { natural antioxidant present in } \\
\text { seminal fluid at concentrations } \\
10-60 \text { times the concentration } \\
\text { in serum }\end{array}$ & $\begin{array}{l}\text { Improve the DNA } \\
\text { damage and breaks, } \\
\text { decrease the abnormal } \\
\text { forms of sperms. }\end{array}$ & \\
\hline Zinc & $\begin{array}{l}\text { cofactor for nearly } 100 \\
\text { enzymes required for biologic } \\
\text { processes such as DNA } \\
\text { transcription and protein } \\
\text { synthesis }\end{array}$ & $\begin{array}{l}\text { Has membrane } \\
\text { stabilizing effects, anti- } \\
\text { apoptotic properties } \\
\text { and acts as direct } \\
\text { antioxidant }\end{array}$ & \\
\hline $\mathrm{N}$-acetyl cysteine (NAC) & $\begin{array}{l}\text { precursor for } \\
\text { glutathione (GSH) }\end{array}$ & antioxidant & \\
\hline Omega-3 fatty acids & Prevent lipid peroxidation & & \\
\hline Corticosteroids & $\begin{array}{l}20 \mathrm{mg} \text { of prednisolone twice } \\
\text { daily for the first } 10 \text { days of } \\
\text { their partner's menstrual cycle } \\
\text { and then received } 5 \mathrm{mg} \text { daily } \\
\text { for days } 11 \text { and } 12 \text {. The } \\
\text { treatment period was } 9 \text { months }\end{array}$ & $\begin{array}{l}\text { Useful in cases of Anti- } \\
\text { sperm antibodies (ASA) } \\
\text { interfere with sperm } \\
\text { motility and sperm } \\
\text { function }\end{array}$ & $\begin{array}{l}\text { weight gain, generalized } \\
\text { infections }\end{array}$ \\
\hline NSAIDS & $\begin{array}{l}25 \mathrm{mg} \text { of COX-2 inhibitors } \\
\text { (rofecoxib) daily for } 30 \text { days }\end{array}$ & $\begin{array}{l}\text { Empirical therapy for } \\
\text { infertile males with } \\
\text { abacterial } \\
\text { leukocytospermia. }\end{array}$ & \\
\hline $\begin{array}{l}\text { Phosphodiesterase- } 5 \\
\text { inhibitors (sildenafil, } \\
\text { tadalafil, vardenafil) }\end{array}$ & $\begin{array}{l}\text { Prevent the hydrolysis of } \\
\text { cGMP, so increasing } \\
\text { intracellular levels of cGMP this } \\
\text { impoves the sperm parameters } \\
\text { especially the acrosome } \\
\text { reaction }\end{array}$ & $\begin{array}{lr}\text { Male infertility due to } \\
\text { erectile dysfunction, } \\
\text { idiopathic } \\
\text { infertility }\end{array}$ & \\
\hline $\begin{array}{lr}\text { Mast-cell } & \text { stabilizers/ } \\
\text { blockers } & \text { (tranilast, } \\
\text { ketotifen) } & \end{array}$ & $\begin{array}{l}\text { High levels of mast cells are } \\
\text { present in semen fluid of } \\
\text { infertile men }\end{array}$ & $\begin{array}{l}\text { Improve } \quad \text { sperm } \\
\text { parameters, decrease } \\
\text { semen WBCS count }\end{array}$ & \\
\hline $\begin{array}{l}\text { Parasympathomimetics } \\
\text { (neostigmine, } \\
\text { physostigmine) }\end{array}$ & Treatment of anejaculation & $\begin{array}{l}\text { significantly more } \\
\text { successful than alpha- } \\
\text { agonists in treatment of } \\
\text { anejaculation or } \\
\text { infertility due to spinal } \\
\text { cord injury }\end{array}$ & $\begin{array}{l}\text { Neostigmine has been } \\
\text { stopped due to invasive } \\
\text { intrathecal delivery and } \\
\text { side-effects as } \\
\text { autonomic dysreflexia } \\
\text { and cerebral } \\
\text { hemorrhage. } \\
\text { Physostigmine has less } \\
\text { severe side-effects. }\end{array}$ \\
\hline
\end{tabular}




\section{Prognosis}

Prognosis of male infertility is variable depending on the underlying cause of infertility. The appropriate evaluation of the patients must be performed to determine the appropriate intervention needed for management of infertility. Prognosis is individualized depending on the results of evaluation and intervention [37]. In the last decades, the significant advancement in the methods of laboratory and radiological diagnosis together with the improvement in the assisted reproductive technologies had significantly improved the prognosis of cases with male infertility [38].

\section{Conclusion}

Male infertility is an important medical condition that significantly affects the quality of life. Diagnosis of male infertility requires full medical history together with performing thorough physical examination. The possible lines of treatment mainly depend on the cause of infertility. Further studies are needed to develop new techniques for management of resistant cases of male infertility.

\section{Compliance with ethical standards}

\section{Acknowledgments}

Many thanks to Dr. Fatma M. Moharm, dermatology and andrology specialist, ministry of health, Egypt for her cooperation for completion of this work.

\section{Disclosure of conflict of interest}

The authors have no conflict of interest to declare.

\section{References}

[1] Kabel AM, Al-Shehri AH, Al-Talhi RA and Abd Elmaaboud MA. (2017). The promising effect of linagliptin and/or indole-3-carbinol on experimentally induced polycystic ovarian syndrome. Chemico Biological Interactions, 273, 190-199.

[2] Marshburn PB. (2015). Counseling and diagnostic evaluation for the infertile couple. Obstetrics and Gynecology Clinics of North America, 42(1), 1-14.

[3] Lotti F and Maggi M. (2014). Ultrasound of the male genital tract in relation to male reproductive health. Human Reproduction Update, 21 (1), 56-83.

[4] El Osta R, Almont T, Diligent C, Hubert N, Eschwège P and Hubert J. (2016). Anabolic steroids abuse and male infertility. Basic and Clinical Andrology, 26, 2.

[5] Kolesnikova LI, Kolesnikov SI, Kurashova NA and Bairova TA. (2015). Causes and Factors of Male Infertility. Vestnik Rossiiskoi Akademii Meditsinskikh Nauk, 5, 579-584.

[6] Foresta C, Selice R, Garolla A and Ferlin A. (2008). Follicle-stimulating hormone treatment of male infertility. Current Opinion in Urology, 18(6), 602-607.

[7] Agarwal A, Mulgund A, Hamada A and Chyatte MR. (2015). A unique view on male infertility around the globe. Reproductive Biology and Endocrinology, 13, 37.

[8] Jensen CFS, Østergren P, Dupree JM, Ohl DA, Sønksen J and Fode M. (2017). Varicocele and male infertility. Nature Reviews Urology, 14(9), 523-533.

[9] Punab M, Poolamets O, Paju P, Vihljajev V, Pomm K, Ladva R, Korrovits P and Laan M. (2017). Causes of male infertility: a 9-year prospective monocentre study on 1737 patients with reduced total sperm counts. Human Reproduction, 32(1), 18-31.

[10] Kumar N and Singh AK. (2015). Trends of male factor infertility, an important cause of infertility: A review of literature. Journal of Human Reproductive Sciences, 8(4), 191-196.

[11] Freeman HJ. (2010). Reproductive changes associated with celiac disease. World Journal of Gastroenterology, 16(46), 5810-5814. 
[12] Samplaski MK and Nangia AK. (2015). Adverse effects of common medications on male fertility. Nature Reviews Urology, 12(7), 401-413.

[13] Pylyp LY, Zukin VD and Bilko NM. (2013). Chromosomal segregation in sperm of Robertsonian translocation carriers. Journal of Assisted Reproduction and Genetics, 30(9), 1141-1145.

[14] Taha EA, Sayed SK, Ghandour NM, Mahran AM, Saleh MA, Amin MM and Shamloul R. (2013). Correlation between seminal lead and cadmium and seminal parameters in idiopathic oligoasthenozoospermic males. Central European Journal of Urology, 66(1), 84-92.

[15] Plaseska-Karanfilska D, Noveski P, Plaseski T, Maleva I, Madjunkova S and Moneva Z. (2012). Genetic Causes of Male Infertility. Balkan Journal of Medical Genetics, 15(Suppl), 31-34.

[16] Cui X, Jing X, Wu X, Yan M, Li Q, Shen Y and Wang Z. (2016). DNA methylation in spermatogenesis and male infertility. Experimental and Therapeutic Medicine, 12(4), 1973-1979.

[17] Barratt CL, Mansell S, Beaton C, Tardif S and Oxenham SK. (2011). Diagnostic tools in male infertility-the question of sperm dysfunction. Asian Journal of Andrology, 13(1), 53-58.

[18] Esteves SC, Miyaoka R and Agarwal A. (2011). An update on the clinical assessment of the infertile male. Clinics, 66(4), 691-700.

[19] Anawalt BD. (2013). Approach to Male Infertility and Induction of Spermatogenesis. Journal of Clinical Endocrinology and Metabolism, 98(9), 3532-3542.

[20] Bieniek JM, Drabovich AP and Lo KC. (2016). Seminal biomarkers for the evaluation of male infertility. Asian Journal of Andrology, 18(3), 426-433.

[21] Wosnitzer MS. (2014). Genetic evaluation of male infertility. Translational Andrology and Urology, 3(1), 17-26.

[22] Ammar T, Sidhu PS and Wilkins CJ. (2012). Male infertility: the role of imaging in diagnosis and management. British Journal of Radiology, 85 (Spec Iss 1), S59-S68.

[23] Alshehri FM, Akbar MH, Altwairgi AK and AlThaqufi OJ. (2015). Preoperative duplex ultrasound parameters predicting male fertility after successful varicocelectomy. Saudi Medical Journal, 36(12), 1439-1445.

[24] Belloc S, Hazout A, Zini A, Merviel P, Cabry R, Chahine H, Copin H and Benkhalifa M. (2014). How to overcome male infertility after 40: Influence of paternal age on fertility. Maturitas, 78(1), 22-29.

[25] Bieniek JM and Sumfest JM. (2014). Sports-related testicular injuries and the use of protective equipment among young male athletes. Urology, 84(6), 1485-1489.

[26] Zheng J-F, Chen X-B, Zhao L-W, Gao MZ, Peng J, Qu XQ, Shi HJ and Jin XL. (2015). ICSI treatment of severe male infertility can achieve prospective embryo quality compared with IVF of fertile donor sperm on sibling oocytes. Asian Journal of Andrology, 17(5), 845-849.

[27] Revenig L, Leung A and Hsiao W. (2014). Ejaculatory physiology and pathophysiology: assessment and treatment in male infertility. Translational Andrology and Urology, 3(1), 41-49.

[28] Ahmadi S, Bashiri R, Ghadiri-Anari A and Nadjarzadeh A. (2016). Antioxidant supplements and semen parameters: An evidence based review. International Journal of Reproductive Biomedicine (Yazd), 14(12), 729736.

[29] Walczak-Jedrzejowska R, Wolski JK and Slowikowska-Hilczer J. (2013). The role of oxidative stress and antioxidants in male fertility. Central European Journal of Urology, 66(1), 60-67.

[30] Crosnoe-Shipley LE, Elkelany 00, Rahnema CD and Kim ED. (2015). Treatment of hypogonadotropic male hypogonadism: Case-based scenarios. World Journal of Nephrology, 4(2), 245-253.

[31] Jung JH and Seo JT. (2014). Empirical medical therapy in idiopathic male infertility: Promise or panacea? Clinical and Experimental Reproductive Medicine, 41(3), 108-114.

[32] Rambhatla A, Mills JN and Rajfer J. (2016). The Role of Estrogen Modulators in Male Hypogonadism and Infertility. Reviews in Urology, 18(2), 66-72.

[33] Ring JD, Lwin AA and Köhler TS. (2016). Current medical management of endocrine-related male infertility. Asian Journal of Andrology, 18(3), 357-363. 
[34] Khajavi N, Akbari M, Abolhassani F, Dehpour AR, Koruji M and Habibi Roudkenar M. (2014). Role of Somatic Testicular Cells during Mouse Spermatogenesis in Three-Dimensional Collagen Gel Culture System. Cell Journal, 16(1), 79-90.

[35] Huleihel M, Nourashrafeddin S and Plant TM. (2015). Application of three-dimensional culture systems to study mammalian spermatogenesis, with an emphasis on the rhesus monkey (Macaca mulatta). Asian Journal of Andrology, 17(6), 972-980.

[36] Moreno I, Míguez-Forjan JM and Simón C. (2015). Artificial gametes from stem cells. Clinical and Experimental Reproductive Medicine, 42(2), 33-44.

[37] Palermo GD, Kocent J, Monahan D, Neri QV and Rosenwaks Z. (2014). Treatment of male infertility. Methods in Molecular Biology, 1154, 385-405.

[38] Campagne DM. (2013). Can Male Fertility Be Improved Prior to Assisted Reproduction through The Control of Uncommonly Considered Factors? International Journal of Fertility and Sterility, 6(4), 214-223.

\section{How to cite this article}

Akilah AA, Kabel AM and Alharthi HA. (2017). New perspectives in male infertility. GSC Biological and Pharmaceutical Sciences, 1(3), 12-19. 